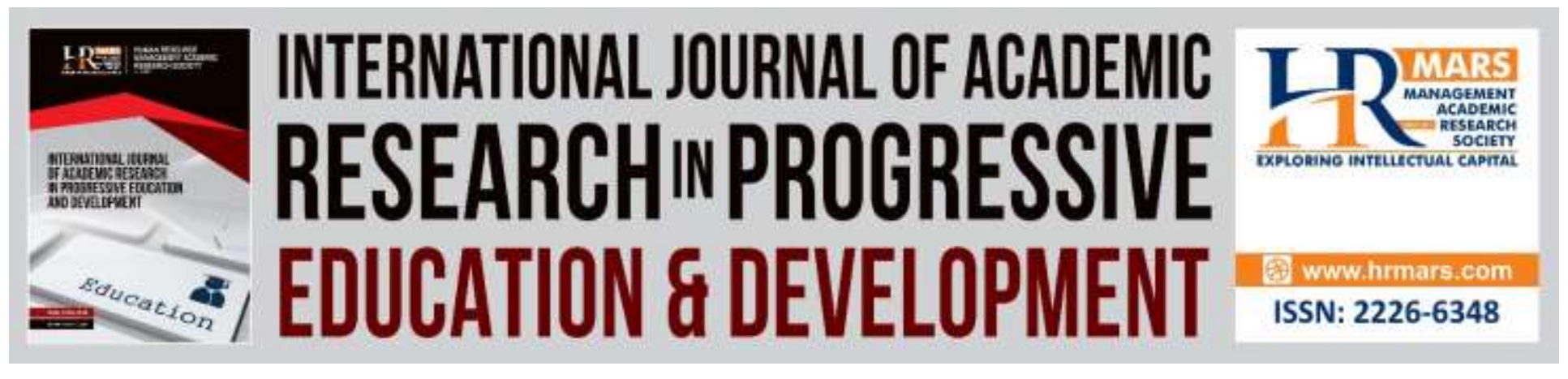

\title{
A Review of Coaching and Mentoring Theories and Models
}

Mastura binti Kamarudin, Azni Yati binti Kamarudin, Ramiaida binti Darmi, Noor Saazai binti Mat Saad

To Link this Article: http://dx.doi.org/10.6007/IJARPED/v9-i2/7302

DOI:10.6007/IJARPED/v9-i2/7302

Received: 21 March 2020, Revised: 27 April 2020, Accepted: 10 May 2020

Published Online: 18 June 2020

In-Text Citation: (Kamarudin et al., 2020)

To Cite this Article: Kamarudin, M. binti, Kamarudin, A. Y. binti, Darmi, R. binti, \& Saad, N. S. binti M. (2020). A Review of Coaching and Mentoring Theories and Models. International Journal of Academic Research in Progressive Education and Development, 9(2), 289-298.

Copyright: (C) 2020 The Author(s)

Published by Human Resource Management Academic Research Society (www.hrmars.com)

This article is published under the Creative Commons Attribution (CC BY 4.0) license. Anyone may reproduce, distribute, translate and create derivative works of this article (for both commercial and non-commercial purposes), subject to full attribution to the original publication and authors. The full terms of this license may be seen at: http://creativecommons.org/licences/by/4.0/legalcode

\section{Vol. 9(2) 2020, Pg. 289 - 298}

Full Terms \& Conditions of access and use can be found at http://hrmars.com/index.php/pages/detail/publication-ethics 


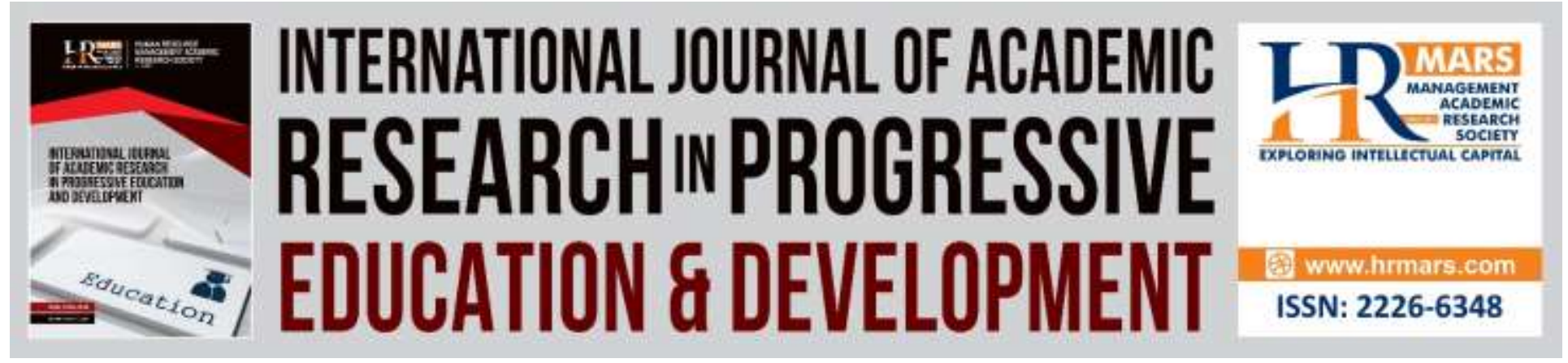

\title{
A Review of Coaching and Mentoring Theories and Models
}

\author{
Mastura binti Kamarudin \\ Universiti Sains Islam Malaysia, 71800, Negeri Sembilan, Malaysia
}

Azni Yati binti Kamarudin

University of Malaya, 50603, Kuala Lumpur, Malaysia

\author{
Ramiaida binti Darmi, Noor Saazai binti Mat Saad \\ Universiti Sains Islam Malaysia, 71800, Negeri Sembilan Malaysia,Malaysia
}

\begin{abstract}
This paper encapsulates the theories and models within the coaching and mentoring process. Three major theories and models are discussed and relate to the coaching and mentoring situation: Zone of Proximal Development (ZPD), Biggs's Presage-Process-Product Model and The GROW Model. These models play a significant role in coaching and mentoring whereby both involve in the process to maximise the potential of the clients or coaches. A series of meeting, building rapport and rightly questioning and answering techniques could build up the best of coaches and clients. At the same time, the mentors must be able to model the action they want their mentee to adopt. Thus, these theories and models should be fully understood and applied by mentors and mentees to increase their quality.
\end{abstract}

Keywords: Coaching, Mentoring, Clients, Theories, Potential.

\section{Introduction}

The aim of this paper is to explore into, and understand, theories and models within the coaching process. The researcher reviewed theories and models related to coaching and mentoring in order to lay a more or less solid foundation upon which coaching and mentoring can be based. Then, the validation of theory and models is established and their contribution to the issue of coaching and mentoring analysed. The review of these theories and models are essential because it helps to unveil a deep concern for the coaching and mentoring relationship. There are two theories and one model that have become the mainstay of this study. They are Zone of Proximal Development (ZPD), Biggs's Presage-Process-Product Model and The GROW Model. They are to be discussed in order. 
INTERNATIONAL JOURNAL OF ACADEMIC RESEARCH IN PROGRESSIVE EDUCATION AND

DEVELOPMENT

Vol. 9, No. 2, 2020, E-ISSN: 2226-6348 @ 2020 HRMARS

\section{Coaching}

Basically, coaching is a central component of successful professional development. According to Whitmore (2002), coaching refers to unlocking a person's potential to maximise their own performance. Du Toit and Reissner (2012) posited that coaching is the ability to increase and improve the sensitivity and awareness that the client has within himself or herself, and for others. To develop self-awareness, an individual must have access to honest feedback and this is sometimes difficult to obtain within the organisation, particularly if the client is in a senior position within the organisation. Coaching is an enabling process aiming at enhancing learning and development with the intention of improving the performance in a specific aspect of practice (Lord et al. 2008). Coaching is the main component of a successful professional development that will become a form of support to reveal a person's potential to maximise their own performance. Coaching offers support for the learners' ability to transfer their learning to succeed in complex and independent performances. According to Lord et al. (2008), coaching is an enabling process that aims at enhancing learning and development with the intention of improving the performance in a specific aspect of the practice (Lord et al., 2008). Therefore, in this study coaching is defined as the ability of a coach to offer additional professional support in helping the coachees to exploit and increase their performance in certain subjects, namely Mathematics, Bahasa Melayu and English Language. The emphasis will be on continuous collaboration, support for lesson planning and teacher placement so that the $21^{\text {st }}$ century teaching and learning in the classroom can become the focal point of their teaching.

\section{Mentoring}

Mentoring refers to a process of serving as a mentor, or someone who facilitates and assists another person's development. The process of mentoring includes modelling because the mentor must be able to model the messages and suggestions being taught to the beginning teacher (Gay, 1995). With regard to this study, mentoring is a process where the SISC+ or the coaches demonstrate a range of cognitive coaching competencies, such as posing carefully constructed questions to stimulate reflection, paraphrasing, and using data to improve teaching and learning. Ganser (2006) stated that mentoring was a tool which had remained very significant in improving management skills and staff development. Hence, mentoring is a dynamic relationship that leads to the creativity, professional growth and mastery over problem-solving techniques. Nonaka and Nishiguchi (2001) mentioned that workplace relationships such as mentoring should be fostered to encourage the transfer of implied knowledge. The nature of mentoring is a collaborative and mutually beneficial approach between mentor and mentee, as Lim (2005) revealed. Thus, mentoring is a factor that promotes guidance on career development and role modelling where both contribute significantly to employee's development. Scandura, Gavin and Williams (2009), emphasised that mentoring relationships can significantly affect individual career development and advancement with both the mentor and the mentee benefiting from the relationship.

\section{Zone of Proximal Development (ZPD) and Scaffolding}

Vygotsky's description of the "zone of proximal development" (ZPD), is the distance between what an individual can achieve individually and what he or she is capable of accomplishing with 
more expert assistance (Vygotsky, 1978). It is vital to note, however, that the term was never used by Vygotsky in his writing, but it was introduced by Wood \& Wood (1996). Cole \& Cole (2001) point out that the term specifies that the support provided goes just slightly beyond the learner's present competence complementing their existing abilities. The key point of the concept developed by Vygotsky refers to the difference between a learner's ability to perform a task independently and guidance.

The theory of Zone of Proximal Development (ZPD) has deliberated by Vygotsky. A ZPD can be created for any field of skill. This concept has a significant contribution to the field of education and is used in developing age-appropriate curriculum and teaching techniques. In the education domain, teaching and learning occur when help is offered at points in the ZPD, at which performance requires help. The assistance is provided by the teacher, the expert, or a more capable person in giving help or assistance. Consequently, teaching consists of assisting performance through the ZPD.

As pointed out by Rasmussen (2001), ZPD is a form of support for the development and learning of children and young people. Jacobs (2001) describes ZPD as the way teachers or peers supply students with the tools they need in order to learn. Under the concept of ZPD mentioned by Vygotsky (1978), individuals learn best when working together with others during collaboration, and it is through such collaborative endeavours with more skilled persons that learners learn and internalise new concepts, psychological tools, and skills.

The term 'scaffolding' as applied to the concept of learning was introduced by Wood, Bruner, and Ross (1976) in their attempt to demonstrate the concept of teaching in the zone of proximal development (ZPD). Researchers believed that the socio-cultural theory of the mind and the concept of ZPD form the basis of the notion of scaffolding (Berk, 2002; Daniels, 2001; Wells, 1999). Nevertheless, there is a distinct understanding and explanation of the differences between ZPD and scaffolding. Wells (1999) definition of scaffolding is a way of operationalising Vygotsky's (1987) concept of working in the zone of proximal development. He introduced three critical features of educational scaffolding. The first is the essentially dialogic nature of the discourse in which knowledge is co-constructed; secondly is the implication of the activity in which knowledge is embedded. Finally, there is the role of artefacts that mediate knowing (Wells, 1999). The primary goal of scaffolding in teaching represents the view on the ZPD characteristics concerning the transfer of task responsibility to the student (Mercer \& Fisher, 1993). They highlight the collaboration between the teacher and the learner in constructing knowledge and skills. With the benefit of scaffolding, after the student has mastered the specific aspect, the task removes the scaffolding to enable the student to try to complete the task again on his own. Once learners have demonstrated their task mastery, the support is decreased, and learners gain responsibility for their growth. A central aspect of scaffolding is related to what Wood, Wood, and Middleton (1978) referred to as the conditional change principle. The principle lies in two folds to "increase control when students fail, and decrease control when students succeed" (Van de Pol \& Elbers, 2013: 33). In this context, the scaffolds act as support to the learner's development. In recent years, scaffolding has been adopted and interpreted in numerous ways to describe all types of support and guidance (Boblett, 2012). Viewed from this perspective, scaffolding is seen both as supportive and liberating (Hammond \& Gibbons, 2005). ZPD holds two related aspects- mediation and scaffolding. When a coach guides his or her coachee, both 
mediation and scaffolding are present. The coach is the mediator while coaching is scaffolding. The idea of a mediator is rather direct, but scaffolding involves some descriptions. In an analysis of scaffolding, Mamour (2008) described that scaffolding is an instructional structure in which the teacher models the desired learning strategy then slowly changes responsibility to the students.

Coaching and scaffolding are two critical components that are addressed together because of similar features. Scaffolding can be categorised as a type of coaching based on the similarities (Collins, Brown, \& Holum, 1991). Based on these realities, this learning theory concerning coaching and mentoring in the education industry is essential to be discussed because as SISC+ their duty is to provide the support needed by their coachees.

\section{Biggs's Presage-Process-Product Model}

Learning is a dynamic process involving learners, learning, and teachers. The awareness of the relationships of the factors that influence learning allows teachers to develop the learning environment that facilitates the learners' efficient learning. Thus, the opportunity to learn is a complex dynamic system that seeks for balance. Biggs's (1996) Presage-Process-Product, or 3P, model was developed to express the interactions between lecturers and students from the opinions of the expectations that both would have regarding the teaching and learning process. The 3Ps model describes 3 points in time at which learning-related factors are placed. This model refers to individual states of being, that foreshadow the educational process. The first stage in Biggs model is the presage stage, which is before the learning takes place while the process means during the learning, and finally, the product is the outcome of the learning. At the individual level, it describes the worldview of each participant in the classroom. According to Prosser and Trigwell (1998), students' approaches to learning are a function of their prior experiences in teaching and learning environments while Ramsden (2003), indicates that a student's approach to study would be influenced by their previous experiences.

In coaching and mentoring, the presage stage describes the prior knowledge, abilities, and skills of the coachee, to learn new knowledge which may or may not impact their learning processes and outcomes. This stage is simultaneously affected by the process and product. Following the Presage stage in the 3P model is the Process stage. In this stage, it refers to the way that coachees characteristics come into play in response to the tasks set by coaches. Process stage referred to how coachees handle the task, and it was determined by their observations towards the coaching context, their motives, and tendencies and their decisions for instant action, all of which include their approach to the learning task. Finally, the Process stage leads to the Product stage of coachees' learning and at this stage, it describes low- and high-level cognitive results that are encompassing from quantitative recall in the case of low-level outcomes, to relevant answers.

This model has provided help to explore the nature of educational opportunities intended to encourage collaborative working because it represents a closed system that can be described as learning processes in any country with students from similar or different cultural, language and educational backgrounds (Biggs, 1996). The nature of the collaborative practice that positively motivates and engages coachees by their respective learning styles, therefore, leads to the framework of this study. This model is essential to describe the contribution of different stages 
Vol. 9, No. 2, 2020, E-ISSN: 2226-6348 @ 2020 HRMARS

in the changes of coachees levels of knowledge skills and abilities after being coached by their respected coaches.

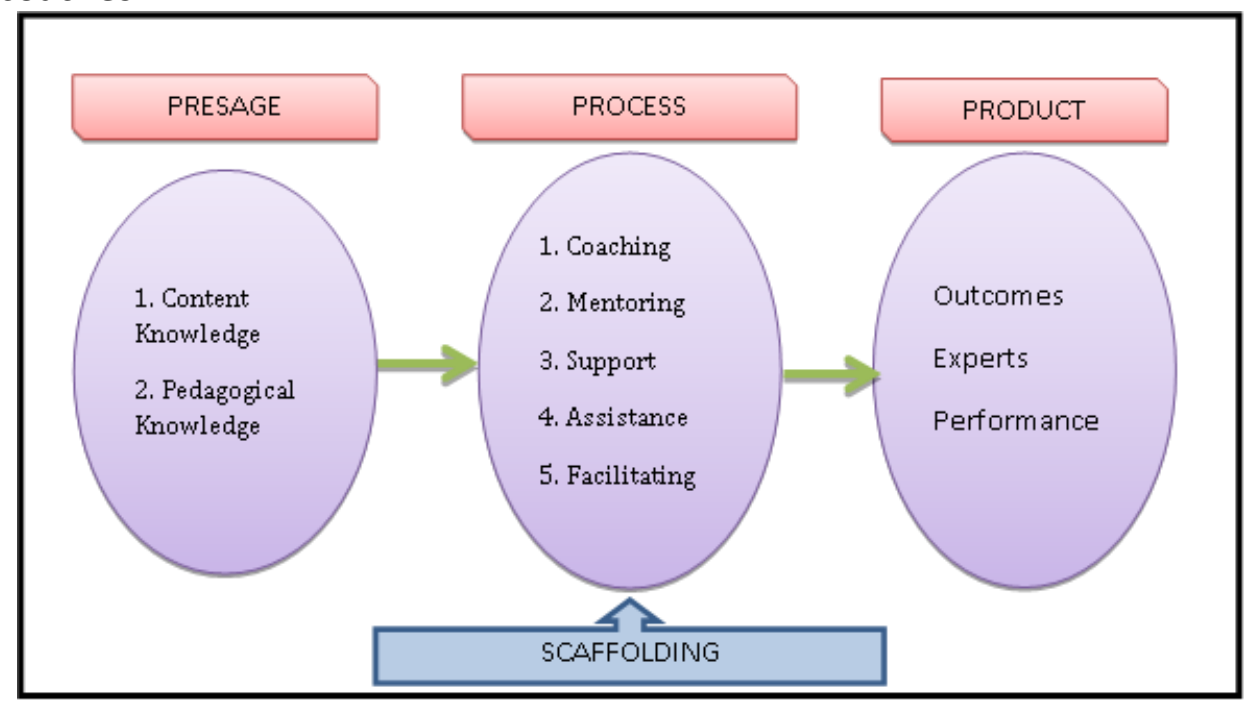

FIGURE 1: Adaptation of Biggs 3Ps Model and Vygotsky Scaffolding

\section{The GROW Model}

One of the more popular coaching models, The GROW model, has gained its popularity since its induction in the 1980s. It was advanced by Alan Fine, Graham Alexander and Sir John Whitmore during the 1980s (Whitmore, 1992). There are also various models and theories of the contribution of coaching to personal improvement. However, while in theory, it is clear what should be done for effective coaching to take place, there is very little research on the effectiveness of coaching (Theeboom et al. 2014).

Mukherjee (2014) stressed that the GROW model is a proven performance coaching instrument that is employed by most companies whenever they dealt with performance issues. According to her, the model's principle behind the GROW model is rooted in the Inner Game theory developed by Timothy Galleway, who was frustrated with the weaknesses of conventional coaching methods in sports (Mukherjee, 2014). In his argument, Galleway said just by witnessing a player's faults and bringing them to his or her attention, does not bring the desired results nor lasting change because people do not keep advice or instructions in their minds for a long time (Parsloe and Leedham, 2016 ). The problem with the instruction is that a player will be able to follow it for a short while but he or she may be unable to keep it in mind in the long term. Galleway realised that, a coach must guide the coachee to reduce internal impairments to performance and this will then result in the flow of natural ability to perform without the coach's input (Mukherjee, 2014). The players result started to improve because the managers, in their role as coaches, help the players through the instructions given so they can gain better access to their own internal resources. Through the knowledge that he gained, he discovered that learning is about learning how to learn, and learning how to think differently. Sir John Whitmore was a student of Galleway, and he then collaborated with Graham Alexander and Alan Fine to develop the GROW model during the early 1980s (Western, 2012). Whitmore's (1992) definition of coaching, which is the process of unlocking an individual's potential to maximise their own 
performance is based on Galleway's views. The structure of the GROW coaching model is shown in the diagram below.

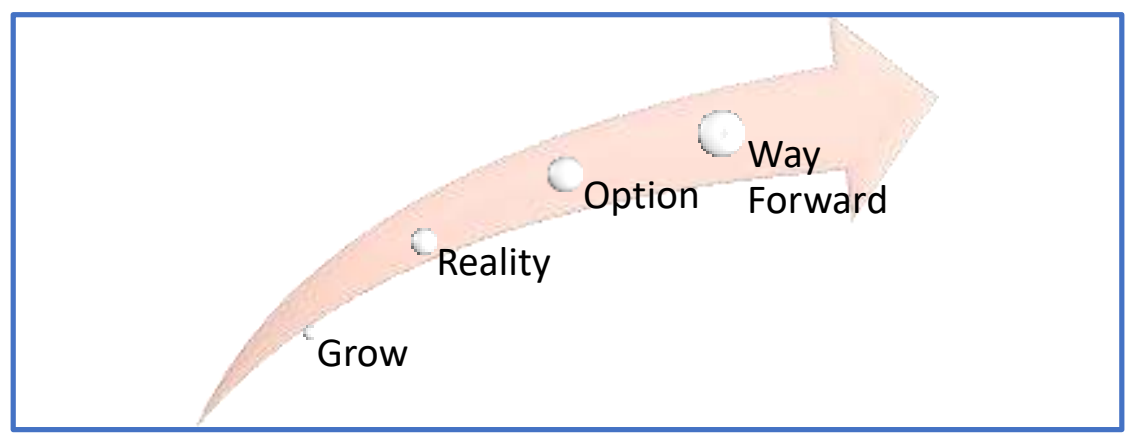

Figure 1. The GROW Model

According to Whitmore (2009), The GROW model helps to solve problems and achieve goals because it is a solution-focused model. There are four stages in the model, which require the coach to captivate the coachee's interest. Each of the four distinct stages was represented by a simple question, or a series of questions to help develop people and discover their potential. It is an ideal model for setting goals, solving problems, preserving personal achievement, and efficiency (Leedham \& Parsloe, 2016).

Firstly, the coach and the coachee needs to establish the goals of the coaching because it is compulsory to know the goal only then both of them can work towards their goals. According to Whitmore (2009), setting goals before exploring into reality helps to develop goals which are not influenced by an individual's current situation. At the same time, the goals must be SMART: Specific, Measurable, Acceptable, Realistic and Timely (Bianco-Mathis et al. 2002). The main question to be addressed when setting goals is whether or not they fit the overall objectives. It is essential to set a goal that is clear and specific. Starr (2016) argues that the idea of setting goals is strongly related to the goal-setting theory, which advocates the setting of clear, specific and challenging goals as this leads to clear direction and motivation.

The second stage is the reality in which the coachee will explain the current reality and what is wrong to help them to see why change is necessary (Weinstein, 2013). It is essential for both the parties to know the current situation because the argument is that it is difficult for them to solve the problem if they do not have a clear picture of the anticipated destination (Whitworth et al. 2007). According to Bridges and Bridges (2017), people cannot solve problems they do not understand or reach goals without considering the starting point. It is vital for the coach and the coachee to keep focus and become aware of the situation. As a coach, the crucial role is to stimulate coachees' self-evaluation and identify the obstacles that have been holding them back. This is the crucial part where the coaches need to summarise and repeat what he or she understands with regard to the actual situation of the coachee. At this phase, it often reveals the fundamental fears and beliefs that can be worked on during or in-between coaching sessions. The option stage is to generate ideas that can contribute to the solution of the problem. It involves exploring into various options and focusing not only on the right answers but on several alternatives to have as many options as possible so that specific action steps can be selected 
(Dembkowski \& Eldridge, 2003). The solutions need to be structured, and then every option needs to be evaluated by creatively brainstorming the process. A coach has to create an environment in which the coachee feels safe to express his or her ideas and thoughts without fear of being judged.

The last step of the GROW coaching model is the choice of one option from the various options stated. Then, the choice is transformed into a more concrete plan. After a well-planned strategy, the coachee's motivation to follow this plan is maximised. The last phase involves converting the discussions into decisions by means of taking specific actions to move forward (Lesley et al. 2015). This is in accordance with the opinion that in coaching, the coach should help individuals to move from their current positions towards greater effectiveness and fulfilment (Lesley et al. 2015). The assumption is that, if questions in each stage are properly dealt with, obstacles that may negatively impact the individual's performance will be reduced (de Haan \& Kasozi, 2015).

As a coach, one of the most critical roles is to guide the coachee to improve their performance by helping them to make better decisions, solve problems that are holding them back. Coach also helps the coachee to acquire new skills and doing things differently, and subsequently, they can progress their careers. The GROW model is grounded on the belief that individuals have the most appropriate solutions to their problems while the coach, on the other hand, will succeed with some proven techniques, practice, and even instincts (Grant, Curtayne \& Burton, 2009).

\section{Conclusion}

In conclusion, theories and models are important aspects in coaching and mentoring relationship. In encapsulation, the review on the theories/model on coaching and mentoring aims at highlighting all the relevant tenets and notions that underpin coaching and mentoring situation. The information of Zone of Proximal Development (ZPD) derived from Vygotsky theory and scaffolding, which provides the ground to this study is central to the chapter. The information gained from the theory is essential to this study since this research is grounded with the learning theory derived from Vygotsky. Likewise, The GROW model developed by Sir John Whitmore, Graham Alexander and Alan Fine, who was a student of Galleway, were also included. The model is significant because it is the foreground work of the coaching and mentoring process.

\section{Acknowledgement}

We thank our colleagues from Universiti Sains Islam Malaysia who provided insight and expertise that greatly assisted the study, although they may not agree with all of the interpretations/conclusions of this paper.

\section{Corresponding Author}

Mastura Kamarudin

Pejabat Pendidikan Daerah Tampin

Universiti Sains Islam Malaysia

Malaysia

Email: masmiera@yahoo.com

NO 2632 Jalan BSS 3/1C Bandar Seremban Selatan 71450 Sg Gadut NSDK 
INTERNATIONAL JOURNAL OF ACADEMIC RESEARCH IN PROGRESSIVE EDUCATION AND

DEVELOPMENT

Vol. 9, No. 2, 2020, E-ISSN: 2226-6348 @ 2020 HRMARS

\section{References}

Berk, L. (2002). Child Development (5th ed.). Boston: Allyn and Bacon.

Bianco-Mathis, V. E., Nabors, L. K., \& Roman, C. H. (2002). Leading from the inside out: $A$ coaching model. California: Sage.

Biggs, J. (1996). Approaches to learning of asian students: A multiple. Asian Contributions to cross-cultural psychology, 4, 180.

Boblett, N. (2012). Scaffolding: Defining the metaphor. Studies in Applied Linguistics and TESOL, 12(2), 1-16.

Cole, M., \& Cole, S. (2001). The development of children (4th ed.). New York: Scientific American Books.

Collins, A., Brown, J. S., \& Holum, A. (1991). Cognitive apprenticeship: MAking thinking visible. American Educator, 15(3), 6-11.

Daniels, H. (2001). Vygoysky \& pedagogy. New York: Routledge.

de Haan, E., \& Kasozi, A. (2015). Coaching leaders through crises. In L. Hall, Coaching in times of crisis \& transformation (pp. 144-171). London: Kogan Page.

Dembkowski, S., \& Eldridge, F. (2003). Beyond GROW: A new coaching model. The international journal of mentoring and coaching, 1(1), 21.

Du Toit, A., \& Reissner, S. (2012). Experiences of coachig in team leading. International journal of mentoring and coaching in education, 1(3), 177-190.

Ganser, T. (2006). A status report on teacher mentoring programmes in the United States. Mentoring in education: An interntional perspective, 33-55.

Gay, G. (1995). Modelling and Mentoring in Urban Education. Education and urban society, 28(1), 103-118.

Grant, A. M., Curtayne, L., \& Burton, G. (2009). Executive coaching enhances goal attainment, resilience and workplace well-being: A randomised controlled study. The journal of positive psychology, 4(5), 396-407.

Hammond, J., \& Gibbons, P. (2005). Putting scaffolding to work: The contribution of scaffolding in articulating ESL education. Prospect, 20(1), 6-30.

Jacobs, G. (2001). Providing the scaffold: A model for early childhood/primary teacher preparation. Early childhood education Journal, 29(2), 125-130.

Leedham, M., \& Parsloe, E. (2017). Coaching and mentoring: Practical techniques for developing learning and performance. London: Kogan Page.

Lim, L. H. (2005). Leadership mentoring in education - The Singapore practice. Singapore: Marshall Cavendish Academic.

Lord, P., Atkinson, M., \& Mitchell, H. (2008). Mentoring and coaching for professionals: A study of the research evidence. Slough: National Foundation for Educational Research.

Ludvigsson, J. F. (2003). Ramsden on learning to teach in higher education. Journal of pediatric gastroenterology and nutrition, 36(4), 511-512.

Mamour, C. T. (2008). The relevance and implication of Vygotsky's sociocultural theory in the second language classroom. Annual Review of Education, Communication and Language Sciences, 5, 244-262.

Mukherjee, S. (2014). Corporate coaching: The essential guide. New Delhi: SAGE Publications India. 
INTERNATIONAL JOURNAL OF ACADEMIC RESEARCH IN PROGRESSIVE EDUCATION AND

DEVELOPMENT

Vol. 9, No. 2, 2020, E-ISSN: 2226-6348 @ 2020 HRMARS

Nonaka, I., \& Nishiguchi, T. (2001). Knowledge emergence: Social, technical, and evolutionary dimensions of knowledge creation. Oxford: Oxford University Press.

Prosser, M., \& Trigwell, K. (1998). Teaching for learning in higher education. Buckingham: Open University Press.

Rasmussen, J. (2001). The importance of communication in teaching: A systems-theory approach to the scaffolding methaphor. Journal of curriculum studies, 33(5), 569-582.

Scandura, C. A., Gavin, M. B., \& Williams, E. A. (2009). Understanding team-level career mentoring by leaders and its effects on team-source learning: The effects of intra-group processes. Human relations, 124-147.

Starr, R. L. (2016). Sociolinguistic variation and acquisition in two-way language immersion: Negotiating the standard. Bristol: Multilingual Matters.

Theeboom, T., Beersma, B., \& van Vianen, A. E. (2014). Does coaching work? A meta-analysis on the effects of coaching on individual level outcomes in an organizational context. The journal of positive psychology, 9(1), 1-18.

Van de Pol, J., \& Elbers, E. (2013). Scaffolding student learning: A micro-analysis of teacherstudent interaction. Learning, culture and social interaction, 2(1), 32-41.

Vygotsky, L. (1978). Mind in society: The development of higher psychological processes. London: Harvard University Press.

Weinstein, N., Brown, K. W., \& Ryan, R. M. (2009). A multi-method examination of the effects of mindfulness on stress attribution, coping, and emotional well-being. Journal of research personality, 43(3), 374-385.

Whitmore, J. (1992). Coaching for performance: A practical guide to growing your own skills. London: Nicholas Brealey Publishing.

Whitworth, L., Kimsey-House, K., Kimsey-House, H., \& Sandahl, P. (2007). Co-active coaching: New skills for coaching people toward success in work and life (2nd ed.). California: Davies-Black Publishing.

Wood, D. (1996). Vygotsky, tutoring and learning. Oxford review of education, 22(1), 5-16.

Wood, D., Bruner, J., \& Ross, G. (1976). The role of tutoring in problem solving. Journal of child psychology and psychiatry, 17, 89-100.

Wood, D., Wood, H., \& Middleton, D. (1978). An experimental evaluation of four face-to-face teaching strategies. International journal of behavioral development, 1, 131-140. 